\title{
PERTEMANAN SEBAYA SEBAGAI ARENA PENDIDIKAN DERADIKALISASI AGAMA
}

\author{
Yusar \\ Universitas Padjadjaran Bandung \\ e-mail: yuzzsar@gmail.com
}

\begin{abstract}
This article was an endeavor to describe the arena of the education which aim to de-radicalization, specially among the youth with their peer group. In many cases, the youth is the main target of the radicalism and they were often exploited for the radical movement. In previous researches, the concept of the peer group are rarely considered. Data collected based on several observations in the experiments with the artificial scene of daily life. The youth found their way to show their awareness on the religious radical movement. In some empirical investigations, this article might offers the theoretical framework of peers that may be constructed to study the de-radicalization of religious movement. In the peer life, it was built the force to control the members not to join the radical movement. This article may provide a new approach in terms of education for deradicalization of religious movement.

Artikel ini merupakan upaya untuk menggambarkan arena pendidikan yang bertujuan untuk deradikalisasi, khususnya di antara kaum muda dengan kelompok sebaya mereka. Dalam banyak kasus, pemuda adalah sasaran utama radikalisme dan mereka sering dilakukan untuk gerakan radikal. Dalam penelitian sebelumnya, konsep dari kelompok sebaya jarang dipertimbangkan. Data dikumpulkan berdasarkan beberapa pengamatan dalam eksperimen dalam adegan buatan kehidupan sehari-hari. Pemuda menemukan jalan mereka untuk memberikan tanda kesadaran gerakan radikal agama. Pada beberapa penyelidikan empiris, artikel ini dapat menawarkan kerangka teoritis teman sebaya yang mungkin dibangun untuk mempelajari deradikalisasi gerakan keagamaan. Dalam kehidupan teman sebaya, dibangun kekuatan untuk mengendalikan anggota untuk tidak bergabung dengan gerakan radikal. Artikel ini dapat memberikan pendekatan baru dalam pendidikan istilah untuk deradikalisasi gerakan keagamaan.
\end{abstract}

Keywords: pertemanan sebaya, remaja, deradikalisasi 


\section{A. Pendahuluan}

Radikalisme agama merupakan salah satu perhatian utama masyarakat dunia dewasa ini, khususnya radikalisme agama. Sejarah bangsa Indonesia diwarnai oleh gerakan radikalisme agama, hal ini memiliki makna bahwa radikalisme agama di Indonesia bukan merupakan yang hal baru. ${ }^{1}$ Perbedaan yang terjadi antara gerakan radikal masa lalu dengan masa sekarang adalah jika pada masa lalu gerakan-gerakan radikal muncul sebagai bentuk perlawanan terhadap pemerintah kolonial, maka pada masa sekarang, gerakangerakan radikal muncul karena terbukanya katup-katup demokrasi. Terbukanya katup-katup demokrasi tersebut pada gilirannya menjadi pintu masuk gerakan radikal baru yang berdasarkan agama di Indonesia.2 Agama dapat menjadi faktor pendorong terjadinya konflik dalam masyarakat terutama saat isu agama digunakan oleh kelompok tertentu. Dalam hal ini agama dijadikan instrumen politik untuk menyalahkan pihak lain yang dianggap tidak memiliki keyakinan yang sama. ${ }^{3}$

Gerakan baru radikalisme agama di Indonesia masa kini dipelopori oleh golongan kaum muda terpelajar. ${ }^{4}$ Golongan tersebut merekrut golongangolongan muda lainnya dan menanamkan doktrin-doktrin gerakan radikal dengan menggunakan terminologi jihād. Survei yang dilakukan oleh Lembaga Kajian Islam dan Perdamaian (LaKIP) menunjukkan bahwa 49\% siswa menunjukkan sikap setuju terhadap aksi radikal terhadap agama. ${ }^{5}$ Guru-guru sekolah menengah yang merupakan golongan terpelajar, diasumsikan adalah

\footnotetext{
1Martin van Bruinessen, "Genealogies of Islamic Radicalism in Post-Suharto Indonesia”, South East Asia Research, Vol. 10, No. 2, 2002, h. 117, http:///www. dspacelibrary.uu.nl/ bitstream/handle/ 1874/20378/bruinessen_02_genealogies_islamicradicalism.pdf?sequence=1, diakses pada tanggal 3 Maret 2015.

${ }^{2}$ Abu Rokhmad, "Radikalisme Islam dan Upaya Deradikalisasi Paham Radikal”, Jurnal Walisongo, Vol 20, No. 1, Mei 2012, h. 79, http://eprints.walisongo.ac.id/1931/1/Abu_Rokhmad-Radikalisme_ Islam. pdf, diakses tanggal 4 Maret 2015.

${ }^{3}$ Sean Byrne dan Amos Nadan, "The Social Cube Analytical Model and Protracted Ethoterritorial Conflicts", dalam Thomas Matyok et al (ed.), Critical Issues In Peace and Conflict Studies, (Plymouth: Lexington Books, 2011), h. 64.

${ }^{4}$ Martin van Bruinessen, "Genealogies of Islamic Radicalism in Post-Suharto Indonesia", South East Asia Research, Vol. 10, No. 2, 2002, h. 117, http:///www.dspace.library.uu.nl/ bitstream/handle/ 1874/20378/bruinessen_02_genealogies_islamicradicalism.pdf?sequence=1, diakses pada tanggal 3 Maret 2015.

${ }^{5}$ Abdul Munip, "Menangkal Radikalisme Agama di Sekolah", Jurnal Pendidikan Islam, Vol. 1 No 2. Desember 2012, h. 160, http://journal.uin-suka.ac.id/jurnal/artikel/133/menangkal-radikalismeagama-di-sekolah, diakses tanggal 2 Februari 2015.
} 
aktivis gerakan Islam yang terkategorikan dalam gerakan baru radikalisme agama tahun 1980-an. Dari para guru itulah pemahaman radikal ditransmisikan kepada para siswa.

Radikalisme agama tidak hanya sebatas pada siswa. Golongan mahasiswa pun memiliki kecenderungan mendukung gerakan radikal atas nama agama. Dari 2.466 responden mahasiswa, sebanyak 1.594 responden (65\%) menyetujui tindakan sweeping kemaksiatan, sebanyak 446 responden (18\%) mendukung dan terlibat aktif dalam kegiatan sweeping kemaksiatan, 268 responden (11\%) tidak menyetujui kegiatan sweeping kemaksiatan, dan 158 responden (6\%) tidak memberikan jawaban. Lebih lanjut, sebanyak 2.170 responden (88\%) menyatakan bahwa kegiatan sweeping tersebut merupakan perintah agama. ${ }^{6}$ Berdasarkan data di atas, dapat diasumsikan bahwa sikap siswa dan mahasiswa tersebut merupakan hasil transmisi gerakan radikalisme dari para guru dan dosennya. Guru dan dosen yang kini bertugas di kampus merupakan produk sejarah, yakni golongan muda dan terpelajar yang memiliki pemahaman serta mendukung gerakan radikal di saat para guru dan dosen duduk di bangku kuliah.

Data di atas ini memberi makna bahwa lembaga pendidikan tidak kedap terhadap paham dan gerakan radikal dengan sasarannya adalah kaum muda. Guru dan dosen merupakan agen-agen penyebar paham radikalisme agama kepada siswa maupun mahasiswanya. Secara sosiologis, paham radikal ditransmisikan secara antar generasi dengan target utamanya adalah kaum muda. Kelak kaum muda saat ini akan menjadi agen-agen gerakan radikal keagamaan. Argumen bahwa kaum muda menjadi agen gerakan radikal keagamaan dinyatakan oleh Muhammad Najib Azca dengan pendekatan psikologi perkembangan yang disandang oleh kaum muda. ${ }^{7}$

Dalam kehidupan remaja, umumnya mereka lebih mempercayai teman daripada orang-orang lain di sekitar mereka, termasuk orang tua. Informasi yang didapat dari teman umumnya lebih didengar, diperhatikan, dan dipercaya untuk dijadikan landasan perilaku bagi seorang remaja. Dalam kehidupan

${ }^{6}$ Abdul Munip, "Menangkal Radikalisme Agama di Sekolah”, Jurnal Pendidikan Islam, Vol. 1 No 2. Desember 2012, h. 160, http://journal.uin-suka.ac.id/jurnal/artikel/133/menangkal-radikalismeagama-di-sekolah, diakses tanggal 2 Februari 2015.

${ }^{7}$ Muhammad Najib Azca, "Yang Muda yang Radikal: Refleksi Sosiologis terhadap Fenomena Radikalisme Kaum Muda Muslim di Indonesia Pasca Orde Baru”, Ma'arif, Vol. 8, No. 1, Juni 2011, h. 27, http:maarifinstitute.org/images/../vol\%20viii\%20no\%201\%20juli\%20201.pdf, diakses pada tanggal 2 Maret 2015. 
remaja, dapat dikatakan bahwa lingkungan pertemanan sebaya adalah suatu institusi yang berpengaruh besar dalam pembentukan kehidupan diri mereka di masa kini dan juga di masa yang akan datang. Pengaruh yang besar tersebut tidak lain karena adanya nilai-nilai yang dipandang sebagai kebenaran bersama dan selalu dipertukarkan dalam interaksi mereka secara internal dalam lingkungan pertemanan sebaya.

Nilai-nilai yang dipertukarkan dalam lingkup pertemanan sebaya pada kaum muda seringkali berkait dengan struktur yang lebih besar. Dalam konteks, fenomena radikalisme agama, nilai-nilai yang dipertukarkan tidak lain merupakan suatu aktivitas pendidikan, yakni pertukaran nilai untuk menghasilkan konsensus kelompok. Dari sudut pandang ini, nilai-nilai radikalisme agama dapat dipertukarkan dalam lingkungan pertemanan sebaya kaum muda dan dijadikan standar nilai bagi kelompok tersebut. Pertukaran nilai-nilai itu akan menyebabkan seorang anggota yang tidak memiliki paham radikal dapat menjadi radikal. Di sisi lain, nilai-nilai Islam yang moderat juga dapat terbangun berdasarkan konsensus. Konsensus yang tercipta dalam kelompok pertemanan sebaya dapat mengubah sikap anggotanya yang berpaham radikal menjadi tidak radikal. Hal ini didasarkan pada konsensus yang dihasilkan dalam kelompok pertemanan sebaya dan konsensus-konsensus selalu tercipta dalam lingkungan pertemanan sebaya.

Dalam konteks pendidikan deradikalisasi agama, pertukaran nilai dan konsensus yang terbangun pada lingkungan pertemanan sebaya, seorang individu dari golongan kaum muda menghadapi berbagai perbedaan cara pandang dan terus menerus dinegosiasikan dalam interaksi sehari-hari. Nilainilai Islam yang bersifat moderat dinegosiasikan terhadap nilai-nilai radikal dalam suatu pertemanan sebaya. Dari perbedaan cara pandang ini, masingmasing individu menyadari perbedaan dan mencari solusi, yakni konsensus yang menengahi kedua nilai yang saling bertentangan. Secara esensial, terjadi proses pendidikan dalam kelompok pertemanan sebaya. Apabila perbedaan tersebut tetap mencuat maka nilai-nilai moralitas kemanusiaan menjadi mengemuka dalam kelompok tersebut. Sikap mana yang pantas dan sikap mana yang tidak pantas dirujuk berdasarkan standar nilai masyarakat yang lebih luas. Proses pendidikan terus berlangsung, yakni pendidikan atas nilainilai moralitas yang disampai dalam suasana dialogis dan non-formal pada lingkungan pertemanan sebaya. 


\section{B. Pertemanan Sebaya dan Ruang Negosiasi}

Dalam karya-karya sebelumnya, dinyatakan oleh Syamsul Rijal dalam tulisannya Radikalisme Islam Klasik dan Kontemporer, fenomena radikalisme Islam diyakini oleh banyak pihak sebagai ciptaan abad ke-20 di dunia Muslim, terutama di Timur Tengah, sebagai produk dari krisis identitas yang berujung pada reaksi dan resistensi terhadap Barat yang melebarkan kolonialisasi di dunia Muslim. Terpecahnya dunia Muslim ke dalam berbagai negara bangsa (nation-state) dan proyek modernisasi yang dicanangkan oleh pemerintah baru berhaluan Barat mengakibatkan umat Islam merasakan terkikisnya ikatan agama dan moral yang selama ini mereka junjung secara kuat. Hal ini menyebabkan munculnya gerakan-gerakan Islam radikal yang menyerukan kembali ke ajaran Islam yang murni sebagai jalan keluar. Tidak sampai di situ, gerakan ini melakukan perlawanan terhadap rezim yang dianggap sekuler dan menyimpang dari agama. ${ }^{8}$

Senada dengan hal tersebut, menurut Azyumardi Azra, gerakan fundamentalisme kontemporer lahir sebagai reaksi terhadap masuknya sistem-sistem, nilai-nilai sosial, kebudayaan, politik, dan ekonomi yang bercorak Barat. Hal tersebut merupakan akibat kontak langsung dengan Barat maupun melalui pemikir Muslim yang berhaluan modernis, sekuler, atau menerapkan nilai-nilai barat dalam pemikiran dan gagasannya. Bagi kaum fundamental dan radikal, pemerintahan di negara-negara berpenduduk Islam merupakan perpanjangan kekuasaan Barat, karena tidak menjalankan sistem pemerintahan yang islami, dari pada kekhilafahan Islam..$^{9}$ Kaum fundamental dan radikal sering menganggap bahwa pemerintahan yang tidak islami adalah thagut yang harus dilawan. ${ }^{10}$

Gerakan radikal terutama dari golongan Islam, telah ada dan mengiringi perjalanan Republik Indonesia, sebagaimana yang diketengahkan oleh Martin van Bruinessen dalam tulisannya "Genealogies of Islamic Radicalism in PostSuharto Indonesia". Bibit-bibit gerakan radikalisme pada golongan Islam di-

\footnotetext{
${ }^{8}$ Syamsul Rijal, "Radikalisme Islam Klasik dan Kontemporer: Membanding Khawarij dan Hizbut Tahrir", Jurnal al-Fikr, Vol. 14, No 2, tahun 2010, http://www.uin-alauddin.ac.id/download5.Syamsul\%20Rijal.pdf, diakses tanggal 2 Februari 2015.

${ }^{9}$ Azyumardi Azra, Pergolakan Politik Islam: Dari Fundamentalisme, Modernisme hingga PostModernisme, (Jakarta: Paramadina, 2006), h. 111.

10Zachary Abuza, Political Islam and Violence In Indonesia, (New York: Routledge, 2007), h. 66.
} 
gagas oleh para kaum muda terpelajar dan menjadikan kampus-kampus sebagai pusat aktivitas gerakannya. Radikalisme di kalangan kaum muda terpelajar tersebut diilhami oleh Revolusi Iran tahun 1979.11

Penelitian Martin van Bruinessen tersebut menyiratkan bahwa kampus sebagai institusi pendidikan formal bukanlah suatu institusi yang kedap terhadap paham-paham radikal. Sejatinya kampus sebagai institusi pendidikan dapat membebaskan manusia dari paham-paham radikal yang seringkali bersifat intoleran dan represif justeru menjadi arena tumbuh kembang paham radikalisme di kalangan muda terpelajar. ${ }^{12}$ Kenyataan bahwa Indonesia merupakan negara multikultur, sikap-sikap intoleran merupakan pengingkaran terhadap realitas kemajemukan bangsa Indonesia. Untuk mengikisnya diperlukan strategi pendidikan dakwah multikultural di sekolah-sekolah untuk membuka wawasan atas realitas kemajemukan bangsa Indonesia. ${ }^{13}$

Tantangan bagi implementasi pendidikan deradikalisasi agama, berdasarkan hasil penelitian terdahulu, sekolah justru menjadi arena bagi para agen paham radikal untuk menyebarkan paham dan menjalankan misinya. Hal ini dikuatkan dengan tingginya angka dukungan dari para siswa dan mahasiswa atas tindakan-tindakan radikal yang terjadi di Indonesia. ${ }^{14}$ Karena itu diperlukan langkah terobosan dalam hal pendidikan guna membatasi paham radikal keagamaan. Dalam hal ini, pendidikan perlu dipandang secara lebih luas, tidak saja hanya mencakup institusi pendidikan formal, pendidikan-pendidikan yang bersifat interaksi antar manusia dalam hidup keseharian sangat mungkin dijadikan arena pendidikan deradikalisasi agama.

Pendidikan merupakan kegiatan manusia sepanjang hidupnya. Pendidikan tidak terjadi hanya dalam institusi pendidikan formal, seperti sekolah atau kampus namun dapat terjadi dalam suatu suasana informal. Pendidikan yang

\footnotetext{
11Martin van Bruinessen, "Genealogies of Islamic Radicalism in Post-Suharto Indonesia, South East Asia Research", Vol. 10, No. 2, 2002, h. 117-154, http:///www. dspacelibrary.uu.nl/bitstream/ handle/ 1874/20378/bruinessen_02_genealogies_islamicradicalism.pdf?sequence=1, diakses pada tanggal 3 Maret 2015

${ }^{12}$ Hairus Salim H.S, Najib Kaelani, dan Nikmal Azekiyah, Politik Ruang Publik Sekolah Negosiasi di Sekolah Menengah Umum Negeri di Yogyakarta,(Yogyakarta: UGM, 2011), h. 28.

${ }^{13}$ Siti Irene Astuti Dwiningrum, "Multicultural Da'wa In Schools From Sociological Perspectives", Walisongo, Vol 22, No. 2, November 2014.

${ }^{14}$ Abdul Munip, "Menangkal Radikalisme Agama di Sekolah”, Jurnal Pendidikan Islam, Vol. 1 No 2. Desember 2012, h. 159-181, http://journal.uin-suka.ac.id/jurnal/artikel/133/menangkal-radikalismeagama-di-sekolah, diakses tanggal 2 Februari 2015.
} 
bersifat informal berkaitan dengan pengalaman-pengalaman dan realita hidup sehari-hari yang dialami oleh anggota masyarakat yang tidak terorganisasi secara jelas, tidak hierarkis, dan proses pembelajarannya bersifat insidental. Pendidikan yang bersifat informal dapat bertempat di berbagai lingkungan tanpa terikat oleh ruang kelas. Transfer dan sharing pengetahuan dapat bersumber dari siapapun, misalkan dari keluarga, teman kerja, teman bermain, media massa, atau perpustakaan. ${ }^{15}$ Dengan kata lain, pendidikan informal dapat terjadi di mana pun, kapan pun, dan oleh siapa pun, termasuk dalam pertemanan sebaya.

Pendidikan informal memiliki muatan agar setiap individu memahami tindakan mereka, menyadari perbedaan sebagai realitas, dan menerima berbagai macam perbedaan sebagai suatu yang asasi dalam masyarakat. Pendidikan memiliki korelasi yang kuat dengan hak asasi manusia. Dinyatakan oleh Lieve Cattrijse, bahwa kebutuhan atas pendidikan hak asasi manusia atau untuk hak-hak pendidikan bagi manusia tidak dapat hanya ditempuh melalui teknik-teknik univocal dan statis. Pendidikan hak-hak asasi manusia merupakan upaya merealisasikan hak-hak asasi manusia dalam kehidupan nyata secara terus menerus, bersama dengan anggota masyarakat yang peduli terhadap hak-hak asasi manusia, termasuk bersama anak-anak ${ }^{16}$ Dari pernyataan tersebut, selaras dengan konteks penelitian, dalam pertemanan sebaya dapat terjadi proses pendidikan informal yang mengarah pada terwujudnya pendidikan mengenai kesadaran hak-hak asasi manusia secara nyata dalam realitas kehidupan sehari-hari anggota pertemanan sebaya.

Kaum muda dalam hal ini adalah golongan berdasarkan umur, yakni berumur antara 13-24 tahun. Kaum muda ini terbagi atas dua golongan, yakni remaja (teenager) yang berusia antara 13-19 tahun dan dewasa muda (young adults) yakni golongan berusia 20-24 tahun. ${ }^{17}$ Pada fase usia tersebut, seorang individu manusia mengalami pencarian identitas diri yang jauh lebih tinggi intensitasnya daripada golongan usia di bawahnya maupun di atasnya. ${ }^{18}$ Pada

\footnotetext{
15Wim Hoppers, Integrating Formal and Non-Formal Basic Education: Policy and Practice in Uganda, (Paris: IIEP, 2008).

${ }^{16}$ Lieve Cattrijse, Human Rights Education: One Step Beyond in Search of a Conceptual Framework for Human Rights Education, (Ghent: Ghent University, 2009).

17United Nations Division for Social Policy and Development, "Definition of Youth", http://www.un. org/esa, diakses pada tanggal 10 Maret 2015.

18Mark Tittley, "Youth Subcultures and Commitment Level Model”, http://www.btc.co.za, diakses tanggal 10 Maret 2015.
} 
masa pencarian diri tersebut, kaum muda menyerap pandangan dari luar dan memilih nilai-nilai yang cocok bagi dirinya. Nilai-nilai yang diserap dan dianggap cocok merupakan kebenaran bagi mereka, termasuk paham-paham radikal keagamaan.

Kaum muda merupakan suatu golongan khas dalam masyarakat. Kehidupan kaum muda seringkali berbeda dengan kehidupan unsur masyarakat lainnya. Kaum muda seringkali dipandang sebagai sub-kebudayaan dari golongan masyarakat yang lebih besar yang memiliki peranan penting dalam masyarakat. Mereka membangun diri sebagai aktor-aktor aktif yang terlibat di dalam suatu relasi dialektis antara dirinya dengan struktur yang lebih besar. Sebagai sebuah budaya, kaum muda mengembangkan standar-standar nilai kelompok yang saling mempengaruhi di antara mereka. Standar-standar nilai itu membangun aspek-aspek esensial bagi keberadaan golongan kaum muda, terbentuk dari kebiasaan dan nilai-nilai yang memiliki makna simbolis bagi anggota-anggotanya. ${ }^{19}$

Para ilmuwan sosial, khususnya di Indonesia seringkali tidak memperhatikan keberadaan kaum muda. Kaum muda merupakan penerus estafet kehidupan dan peradaban manusia di dunia. Di sisi lain, kaum muda adalah golongan kreatif yang selalu memunculkan gagasan-gagasan baru yang juga sangat mungkin saling bertentangan dengan gagasan-gagasan yang telah ada sebelumnya dalam struktur masyarakat. Nilai-nilai dalam sub-kultur kaum muda dinegosiasikan secara internal dalam lingkup pertemanan sebaya. Negosiasi nilai-nilai dalam sebuah pertemanan sebaya seringkali mengubah perilaku anggotanya menjadi sesuai dengan perilaku yang diharapkan oleh kelompok. Hal ini memiliki makna bahwa di dalam lingkungan pertemanan sebaya di kalangan kaum muda, terdapat nilai standar yang menjadi patokan baku bagi mereka untuk berpikir dan bertindak. ${ }^{20}$

Pertemanan sebaya dipandang penting dalam melihat kehidupan kaum muda. Dalam kehidupan sehari-harinya, kaum muda dapat dikatakan selalu berada dalam lingkungan pertemanan sebayanya secara intim dan bersifat pribadi. Kehidupan kaum muda sangat sarat diwarnai oleh informasi dan nilai-nilai yang mereka dapatkan dalam lingkungan pertemanan sebaya. Abercrombie dan Warde mengemukakan bahwa kaum muda lebih mempercayai teman daripada

\footnotetext{
${ }^{19}$ Mike Brake, The Sociology of Youth Culture and Youth Subculture: Sex, Drugs and Rock ' $n$ ' Roll, (New York: Routledge, 2013), h. 9.

20 Mike Brake, The Sociology of Youth Culture ...., h. 10-11.
} 
keluarga, hal ini didukung dengan fakta bahwa lebih dari 80\% kaum muda di Inggris menceritakan pengalaman-pengalaman pribadinya kepada teman daripada kepada keluarganya. Abercrombie dan Warde pun secara tersirat memberikan suatu pandangan nomotetik yang dapat dirangkum mengenai ciri kaum muda, yang terdiri atas: (1) Maraknya budaya santai yang bukan bekerja. (2) Hubungan-hubungan sosial kaum muda berada di sekitar keloompok pertemanan sebaya, baik secara kolektif maupun individual. (3) Ditandai dengan kepedulian terhadap gaya. ${ }^{21}$

Hal ini menyiratkan bahwa dalam kehidupan sehari-hari kaum muda, mereka tidak dapat dilepaskan dari lingkungan pertemanan sebayanya. Lingkungan pertemanan sebaya dapat berupa lingkungan pertemanan biasa, yakni dalam jumlah yang banyak seperti sekolah, kampus, atau organisasi, atau dalam lingkungan clique (klik), yakni kelompok kecil dengan jumlah anggota antara 3 hingga 13 orang. ${ }^{22}$

Umumnya kaum muda selalu tergabung dalam suatu ikatan klik. Pada suatu kelompok klik, interaksi antar individu berjalan intim, pribadi, dan terbuka. Kaum muda dalam klik melibatkan suasana keperdulian antar anggotanya dalam ikatan yang melibatkan hubungan emosional. Kaum muda tidak ragu untuk menukarkan kode-kode pemikiran, gagasan, atau perasaannya kepada anggota kliknya. Dalam klik, terjadi pula hubungan saling mempengaruhi antara anggotanya, sekaligus terjadi pertukaran nilai-nilai yang dianggap kebenaran bagi seorang individu dengan individu lainnya.

Dalam klik, individu membagikan pengalaman-pengalaman pribadinya melalui serangkaian interaksi yang terkodekan dalam bentuk bahasa verbal. Kode-kode ini mendapat tanggapan dari individu-individu lainnya, baik tanggapan yang mendukung ataupun yang menyanggah kode yang disampaikan. Tanggapan-tanggapan yang bersifat positif maupun negatif, ditanggapi pula oleh si pemberi kode di awal. Dengan demikian tercipta suatu saling membagi (sharing) kode di antara mereka mengenai realitas kehidupan sehari-hari antar anggota klik tersebut. Dalam lingkungan pertemanan sebaya tercipta pengetahuan mereka tentang dunia karena sharing kode yang dilakukan dalam

\footnotetext{
${ }^{21}$ Nicholas Abercrombie dan Alan Warde, Contemporary British Society Third Edition, (Cambridge: Cambridge University Press, 2000).

22 Bradford B. Brown dan Christa Klute, "Cliques, Crowds, and Friendships”, dalam Gerald R. Adams and Michael D. Berzonsky, Blackwell Handbook of Adolescence, (Malden: Blackwell, 2003), h. 330-348.
} 
interaksi antar anggotanya. Para aktor saling mendistribusikan pengetahuan, baik yang murni berasal dari pengalamannya sendiri ataupun dengan "meminjam" pengalaman orang lain. ${ }^{23}$ Dalam terminologi Garfinkel, hal tersebut dinyatakan sebagai report, yakni pelaporan-pelaporan untuk membuat pengertian terhadap dunia. ${ }^{24}$ Distribusi pengetahuan di antara mereka saat berinteraksi dalam kelompok seringkali terjadi tanpa disadari oleh para aktor.

Pembentukan pengetahuan mengenai dunia membuat para aktor tersadar akan kekhasan masing-masing dan juga melihat standar-standar nilai yang berlaku dalam masyarakat. Kekhasan masing-masing individu dan standarstandar nilai yang berlaku dalam masyarakat mendorong seorang individu untuk berperilaku sesuai dengan yang diharapkan oleh individu lain dan juga masyarakat luas. Individu-individu mulai menata citra dirinya agar diterima oleh kelompok dan juga masyarakat luas. Hal ini memiliki makna bahwa dalam berinteraksi, seorang individu perlu menata dirinya untuk tampil berdasarkan peran-peran yang diharapkan oleh orang lain. Dalam ranah kognitif seorang individu yang terus menerus menata perannya terjadi proses perubahan pemahaman atas nilai-nilai yang ia anut sebelumnya. Pada ranah afektif, terdapat penerimaan atas perbedaan, dan pada ranah psikomotorik, individu tersebut mengganti perilakunya seperti yang diharapkan oleh orang lain. Dengan kata lain, individu tersebut menyesuaikan diri untuk menjadi bagian masyarakat dan budaya yang berlaku dalam lingkungannya. ${ }^{25}$

Dari kajian pustaka di atas, dapat ditarik suatu hipotesis kerja dalam konteks pendidikan deradikalisasi agama. Hipotesis ini mengarahkan pada metode pengambilan data, yakni dalam suatu lingkungan pertemanan sebaya terdapat anggota-anggotanya yang menentang paham-paham radikal maka anggota lain di dalam kelompok tersebut yang mendukung paham radikal akan akomodatif, mengubah pandangan radikalnya,dan mengubah perilaku menjadi lebih moderat agar dapat diterima oleh lingkungan pertemanan sebayanya. Proses pendidikan deradikalisasi agama lebih efektif dilakukan dalam pertemanan sebaya yang bersifat dialogis dan nonformal.

${ }^{23}$ E.C.Cuff, W.W.Sharrock dan D.W.Francis, Perpectives In Sociology Fifth Edition, (New York: Routledge, 2006), h. 131-135.

${ }^{24}$ George Ritzer, Teori Sosiologi dari Sosiologi Klasik hingga Perkembangan Terakhir Postmodern, ed. VIII, 2012, terj. (Yogyakarta: Pustaka Pelajar), h. 670.

25Thomas J. Scheff, Goffman Unbound! A New Paradigm For Social Science, (London: Paradigm Publisher, 2006), h. 16. 


\section{Memahami Fenomena Pertemanan Sebaya dengan Pendekatan Etnometodologi}

Mengacu pada konteks dari artikel ini untuk menggambarkan pertemanan sebaya sebagai arena pendidikan deradikalisasi agama, pendekatan yang dilakukan adalah pendekatan kualitatif dengan mengkonstruksi etnometodologi Garfinkel. Pendekatan etnometodologi dianggap penting karena berbeda dengan sosiologi konvensional yang seringkali gagal menangkap realitas pada kelompok kecil dan juga menawarkan wawasan penelitian dan sikap intelektual baru. ${ }^{26}$ Berdasarkan metode yang dilakukan, penelitian yang telah dilakukan adalah menggambarkan pendidikan deradikalisasi agama di luar institusi pendidikan formal, khususnya pada kaum muda.

Serangkaian pengamatan dan pendengaran dilakukan untuk mengkaji cara para kelompok pertemanan sebaya dalam mengorganisasikan, memahami kegiatan mereka, dan saling menegosiasikan nilai-nilai dalam kelompoknya. Proses pengamatan dan pendengaran dilakukan kepada 8 (delapan) kelompok klik kaum muda kelas menengah terpelajar, yakni siswa SMA dan mahasiswa di Kota Bandung dan Jatinangor. Proses pengamatan dan pendengaran dilakukan sejak April tahun 2014 hingga Februari tahun 2015.

Serangkaian eksperimen berupa simulasi dilakukan kepada 2 (dua) kelompok klik kaum muda kelas menengah terpelajar, yakni mahasiswa di kampus Universitas Padjadjaran dalam setting yang disusun sealamiah mungkin untuk mendapatkan dialog pertukaran nilai-nilai dalam kelompok dengan menghadirkan kaum muda berpandangan radikal dengan kaum muda berpandangan moderat. Pertukaran nilai-nilai dalam selubung kode-kode bahasa dan sikap tubuh mencerminkan bahwa setiap peserta simulasi saling memahami apa yang mereka ujarkan.

Analisis data dilakukan dengan memperhatikan percakapan-percakapan yang terjadi, perubahan-perubahan cara pikir, sikap, dan citra pada anggota klik yang terjadi dalam setiap proses sharing kode. ${ }^{27}$ Perubahan sikap dari anggota kelompok klik dapat ditangkap baik melalui pengamatan maupun pendengaran yang dilakukan oleh peneliti secara interpretif yang dapat dikonfirmasi kebenarannya oleh anggota-anggota klik yang diteliti.

\footnotetext{
${ }^{26}$ Alain Coulon, Etnometodologi, cet. III, (Jakarta: Lengge, 2008).

${ }^{27}$ George Ritzer, Teori Sosiologi ..., h. 674.
} 


\section{Pertemanan Sebaya sebagai Arena Pendidikan Deradikalisasi Gerakan Keagamaan}

Kaum muda menghabiskan kehidupan sehari-harinya dalam suasana pertemanan sebaya. Seperti yang diutarakan oleh Abercrombie dan Warde mengenai karakteristik kaum muda masa kini, kaum muda di Indonesia pun kurang lebih memiliki karakteristik yang sama, terutama dalam hal hubungan-hubungan sosial yang terjadi di antara mereka, yakni berada dalam lingkup pertemanan sebaya dan berbentuk klik. ${ }^{28}$ Suasana pertemanan sebaya di kalangan kaum muda tidak hanya terjadi lingkungan kampus, di luar kampus pun hubunganhubungan sosial kaum muda berada dalam ranah pertemanan sebaya.

Berdasarkan hasil dari konstruksi etnometodologi yang dilakukan sejak kemunculan berita mengenai gerakan radikal Islamic State of Iraqi and Syam (ISIS) didapatkan pemahaman awal mengenai pendidikan deradikalisasi agama dalam lingkungan pertemanan kaum muda yang terkonseptualisasikan dalam beberapa kategori seperti berikut: pertama, Kaum muda yang berasal dari masyarakat berpenghasilan rendah dan tidak terpelajar, tidak terdapat adanya pandangan radikal di antara mereka. Sharing kode berkisar mengenai kesenangan-kesenangan keseharian yang bersifat profan. Temuan ini dijadikan residu data yang mungkin dapat berguna bagi penelitian atau kajian lain.

Kedua, kaum muda terpelajar yang berasal dari kelas menengah, baik siswa maupun mahasiswa terdapat pandangan untuk membenarkan paham ataupun gerakan radikal berbasis agama Islam. Pada golongan ini pun terdapat pandangan yang menentang paham dan gerakan radikal, dan lebih menentang jika paham atau gerakan radikal tersebut diimplementasikan dalam kehidupan nyata. Temuan ini dijadikan bahan untuk ditelusuri lebih lanjut.

Ketiga, kaum muda terpelajar yang berasal dari golongan masyarakat berpenghasilan tinggi, hanya sedikit yang menaruh perhatian terhadap paham dan gerakan radikal. Secara sikap, mereka menentang paham dan gerakan radikal. Umumnya kaum muda terpelajar yang berasal dari golongan berpenghasilan tinggi, bersikap apatis terhadap isu-isu radikalisme agama. Temuan ini dijadikan residu data yang mungkin berguna bagi penelitian atau kajian lain.

${ }^{28}$ Lihat Nicholas Abercrombie dan Alan Warde, Contemporary British Society Third Edition, (Cambridge: Cambridge University Press, 2000). 
Tabel 1.

Pandangan Kaum Muda Terpelajar Berdasarkan Golongan Ekonomi terhadap Paham dan Gerakan Radikal Agama

\begin{tabular}{|l|c|c|}
\hline \multicolumn{1}{|c|}{ Kaum Muda Terpelajar } & $\begin{array}{c}\text { Dukungan terhadap } \\
\text { Paham dan Gerakan } \\
\text { Radikal }\end{array}$ & $\begin{array}{c}\text { Penentangan terhadap } \\
\text { Paham dan Gerakan } \\
\text { Radikal }\end{array}$ \\
\hline $\begin{array}{l}\text { Golongan Masyarakat } \\
\text { Berpenghasilan Tinggi }\end{array}$ & - & + \\
\hline $\begin{array}{l}\text { Golongan Kelas Masyarakat } \\
\text { Berpenghasilan Menengah }\end{array}$ & ++ & ++ \\
\hline Golongan Berpenghasilan Rendah & - & - \\
\hline
\end{tabular}

Sumber: Pengumpulan Data Tahun 2014.

Dari temuan awal, fokus perhatian adalah pada kaum muda terpelajar yang berasal dari golongan kelas menengah karena terdapat dua pandangan yang saling bertentangan, yakni mendukung radikalisme agama dan menentang radikalisme agama. Temuan ini sangat penting, karena membuka kategori baru, tidak seluruh kaum muda menaruh perhatian pada isu radikalisme agama. Kaum muda terpelajar dari golongan menengah adalah golongan yang menaruh perhatian atas isu radikalisme agama, baik yang mendukung maupun menentang radikalisme agama.

Dari serangkaian observasi, pendengaran, dan simulasi diperoleh pola yang relatif tetap. Dalam suasana lingkungan klik, baik siswa SMA maupun mahasiswa terjadi sharing kode berupa pandangan dan pemahaman atas isu radikalisme agama. Serangkaian dialog yang melibatkan pengetahuan-pengetahuan individual atas dukungan ataupun penentangan terhadap paham radikalisme agama dipertukarkan di antara mereka. Individu menempatkan diri mereka pada posisi yang berlawanan guna mendapatkan pemahaman-pemahaman dari lawan bicara. Proses dialog dalam interaksi pertemanan sebaya kaum muda terpelajar golongan kelas menengah merupakan pertukaran pengalaman dan persepsi mereka atas dunia di mana mereka hidup dan bermakna bagi diri masingmasing. ${ }^{29}$ Masing-masing individu mempertahankan pandangan mereka dan saling menegasikan pandangan dari lawan bicara.

\footnotetext{
${ }^{29}$ Darren Lagdridge, Phenomenological Pschycology: Theory, Research, and Methods, (London: Pearson, 2007), h. 4 .
} 
Dari observasi-observasi, pendengaran, dan simulasi yang dilakukan, individu yang menentang paham radikal, meski mempertahankan argumennya, cenderung memilih sikap untuk mendengarkan lawan bicaranya dan mengalah. Sebaliknya, individu yang mendukung paham dan gerakan radikal cenderung berapi-api dan menginginkan lawan bicaranya menerima pandangannya untuk mendukung paham dan gerakan radikal. Hal ini terjadi secara berulang dan membentuk pola dialog yang tetap antar individu dalam suatu kelompok pertemanan sebaya.

Pengetahuan tentang dunia yang terbentuk dari dialog tersebut adalah menguatnya pemahaman atas keragaman pandangan dari individu-individu yang menentang paham dan gerakan radikalisme agama. Di sisi lain, individuindividu tersebut berupaya untuk mempertahankan keutuhan klik mereka, meskipun di dalamnya terdapat nuansa konflik keyakinan atau pandangan hidup. Artinya, pada individu-individu penentang gerakan keagamaan, terjadi proses pendewasaan diri untuk menerima perbedaan-perbedaan pandangan, sebagai konsekuensi dari kehidupan manusia yang beragam. Sebaliknya, dari sisi pendukung paham dan gerakan radikal, cenderung untuk intoleran terhadap perbedaan, meskipun terhadap teman dekatnya di dalam suatu klik. Suasana ini terangkum dalam tabel 2 di bawah:

Tabel 2.

Suasana Dialog antara Pendukung dan Penentang Paham dan Gerakan Radikal Keagamaan dalam Lingkup Pertemanan Sebaya/Clique Tahap Awal

\begin{tabular}{|l|l|l|l|l|l|}
\hline $\begin{array}{c}\text { Paham dan } \\
\text { Gerakan } \\
\text { Radikal } \\
\text { Keagamaan }\end{array}$ & Ketegangan & $\begin{array}{c}\text { Penerimaan } \\
\text { Perbedaan }\end{array}$ & $\begin{array}{c}\text { Argumentatif/ } \\
\text { Rasional }\end{array}$ & Reflektif & $\begin{array}{c}\text { Perubahan } \\
\text { Sikap }\end{array}$ \\
\hline Pendukung & +++ & --- & --+ & --- & --- \\
\hline Penentang & ++- & +++ & ++- & ++- & --- \\
\hline
\end{tabular}

Sumber: Pengumpulan Data Tahun 2014.

Tabel 2 di atas menunjukkan terjadi ketegangan atau konflik dalam lingkungan pertemanan sebaya. Penerimaan perbedaan terdapat pada pihak penentang paham dan gerakan radikal, di sisi lain, pendukung paham dan gerakan radikal memiliki sikap tidak menerima perbedaan. Argumentasi yang rasional cen- 
derung dinyatakan oleh penentang dibandingkan dengan pendukung paham dan gerakan radikal. Sikap reflektif ditunjukkan oleh penentang, sementara dari sisi pendukung tidak menujukkan sifat reflektif dalam relung rohaninya. Dalam hal perubahan sikap, tidak terjadi perubahan sikap pada dua pihak.

Pada pengamatan, pendengaran, dan simulasi berikutnya, terjadi dialog serupa dan dengan posisi yang sama. Pihak penentang paham dan gerakan radikal mengeluarkan argumen-argumen mengenai moralitas, mana yang pantas dan mana yang tidak pantas untuk dilakukan. Berdasarkan pertimbangan rasional atas realitas, anggota-anggota klik yang menjad penentang radikalisme agama memaparkan bahwa gerakan radikal keagamaan menimbulkan stigma di masyarakat. Tidak hanya bagi manusianya tetapi juga stigma bagi agamanya. Dari pengamatan atas mimik muka para aktor yang berdialog, terlihat perubahan wajah pada individu-individu pendukung paham dan gerakan radikal. Perubahan wajah tersebut menunjukkan adanya kesan bahwa mereka tidak dapat memberikan argumen yang tepat untuk membalas argumen yang diberikan oleh individuindividu penentang paham dan gerakan radikal. Hal ini membuat suasana sharing kode menjadi lebih "sejuk" karena individu-individu pendukung paham dan gerakan radikal lebih memilih untuk menjadi pendengar dan menerima kode-kode yang disampaikan oleh individu-individu penentang paham dan gerakan radikal. Suasana ini terangkum dalam tabel 3 di bawah:

Tabel 3.

Suasana Dialog antara Pendukung dan Penentang Paham dan Gerakan Radikal Keagamaan dalam Lingkup Pertemanan Sebaya/Clique Tahap Berikut

\begin{tabular}{|l|c|c|c|c|c|}
\hline $\begin{array}{c}\text { Paham dan } \\
\text { Gerakan } \\
\text { Radikal } \\
\text { Keagamaan }\end{array}$ & Ketegangan & $\begin{array}{c}\text { Penerimaan } \\
\text { Perbedaan }\end{array}$ & $\begin{array}{c}\text { Argumentatif/ } \\
\text { Rasional }\end{array}$ & Reflektif & $\begin{array}{c}\text { Perubahan } \\
\text { Sikap }\end{array}$ \\
\hline Pendukung & ++- & --+ & --+ & --+ & --+ \\
\hline Penentang & +-- & +++ & +++ & +++ & --- \\
\hline
\end{tabular}

Sumber: Pengumpulan Data Tahun 2014.

Tabel 3 di atas menunjukkan bahwa ketegangan atau konflik dalam lingkungan pertemanan sebaya cenderung menurun. Penerimaan perbedaan secara konsisten terdapat pada anggota-anggota kelompok penentang paham 
radikal. Di sisi lain, pendukung paham radikal mulai memiliki sikap menerima perbedaan. Argumentasi yang rasional secara konsisten dinyatakan oleh penentang dibandingkan dengan pendukung paham dan gerakan radikal. Sikap reflektif ditunjukkan oleh penentang, sementara dari sisi pendukung mulai menunjukkan sifat reflektif dalam relung rohaninya. Dalam hal perubahan sikap, mulai terjadi perubahan sikap pada pihak pendukung, di sisi lain tidak terjadi perubahan sikap pada pihak penentang paham dan gerakan radikal.

Pandangan dengan pendekatan multikultur dari individu-individu penentang paham dan gerakan radikal di-sharing-kan kepada individu-individu pendukung paham dan gerakan radikal. Para aktor membagikan pengetahuan mereka atas dunia yang plural dan di sisi lainnya terdapat aktor yang menerima pengetahuan atas dunia yang mungkin selama ini mereka abaikan. Sharing kode-kode mengenai realitas dunia yang plural tersebut berjalan dalam dialog yang interaktif namun hegemonis. Refleksi terjadi pada relung rohani dari pihak pendukung paham dan gerakan radikal yang membuatnya menjadi lebih lunak. Sebagai mana dikatakan oleh Ignas Kleden dalam kritiknya terhadap habitus dari Bourdieu, kehidupan rohani menuntut refleksi secara terusmenerus dengan rujukan yang sadar kepada nilai-nilai umum yang berlaku dalam masyarakat dan motivasi yang melandasi suatu tindakan ${ }^{30}$ Refleksi dalam kehidupan rohani para pendukung paham dan gerakan radikal keagamaan dapat mengarahkan pada perubahan habitus atau membentuk habitus baru. Suasana ini terangkum dalam tabel 4 .

Tabel 4 berikut menunjukkan bahwa ketegangan atau konflik dalam lingkungan pertemanan sebaya semakin menurun. Penerimaan perbedaan secara konsisten terdapat pada pihak penentang paham dan gerakan radikal, di sisi lain, pendukung paham dan gerakan radikal semakin memiliki sikap menerima perbedaan. Argumentasi yang rasional secara konsisten dinyatakan oleh penentang dibandingkan dengan pendukung paham dan gerakan radikal. Sikap reflektif secara tetap ditunjukkan oleh penentang dengan kuat, sementara dari sisi pendukung mulai menunjukkan kenaikan sifat reflektif dalam relung rohaninya. Dalam hal perubahan sikap, semakin terjadi perubahan sikap pada pihak pendukung, di sisi lain tidak terjadi perubahan sikap pada pihak penentang paham dan gerakan radikal.

\footnotetext{
30Ignas Kleden, "Pierre Bourdieu dan Konsep Habitus Baru”, http://www.habitusbaru.com, diakses pada tanggal 4 Maret 2015.
} 


\section{Tabel 4.}

Suasana Dialog antara Pendukung dan

Penentang Paham dan Gerakan Radikal Keagamaan dalam Lingkup Pertemanan Sebaya/Clique Tahap Lanjutan

\begin{tabular}{|l|l|l|l|l|l|}
\hline $\begin{array}{c}\text { Paham dan } \\
\text { Gerakan } \\
\text { Radikal } \\
\text { Keagamaan }\end{array}$ & Ketegangan & $\begin{array}{c}\text { Penerimaan } \\
\text { Perbedaan }\end{array}$ & $\begin{array}{c}\text { Argumentatif/ } \\
\text { Rasional }\end{array}$ & Reflektif & $\begin{array}{c}\text { Perubahan } \\
\text { Sikap }\end{array}$ \\
\hline Pendukung & +-- & -++ & --+ & -++ & -++ \\
\hline Penentang & --- & +++ & +++ & +++ & --- \\
\hline
\end{tabular}

Sumber: Pengumpulan Data Tahun 2015.

Habitus atau skema kognitif dari individu-individu yang menciptakan tindakannya, ${ }^{31}$ mengalami pergeseran, yakni dari mendukung paham dan gerakan radikal menjadi lebih bersedia untuk menerima kenyataan keragaman yang terdapat di sekitarnya dan juga mengarahkan pandangannya pada nilainilai yang dianggap pantas dalam budaya masyarakatnya yang lebih luas. Hal ini dapat dimaknai bahwa proses pendidikan deradikalisasi telah berjalan dalam lingkungan pertemanan sebaya.

Dari data yang didapat menunjukkan bahwa pertemanan sebaya merupakan arena pendidikan deradikalisasi agama yang bersifat dialogis dengan mempertemukan individu-individu yang memiliki pandangan yang berbeda atas radikalisme agama. Hal tersebut menunjukkan bahwa dalam kehidupan nyata, pendidikan deradikalisasi telah berjalan dalam suasana informal yang dilakukan khususnya oleh kaum muda dengan jangkauan pendidikan deradikalisasi yang berskala mikro, yaitu pada tingkat individu dalam kelompok kecil, sesuai dengan metode yang digunakan.

\section{E. Kesimpulan}

Pendidikan deradikalisasi agama dapat ditempuh melalui pendidikan yang bersifat informal, yakni pada lingkungan pertemanan sebaya. Dari artikel ini dapat ditarik empat faktor kekuatan pendidikan deradikalisasi agama dalam

\footnotetext{
31Robertus Robert dan U. Abdul Rojak, "Proses Sosial Sebagai Medium Pembelajaran: Konseptualisasi Habitus Untuk Sosiologi-Pedagogis”, Jurnal Sosialita, Vol. 9, No. 1. Juni, 2011, h. 81, http:// unj.ac.id/fis/sites/default/files/eman_sosialita_912011_0.pdf, diakses pada tanggal 4 Maret 2015.
} 
lingkungan pertemanan sebaya kaum muda secara informal. Pertama, standar nilai kelompok yang dianggap sebagai konsensus dalam kelompok pertemanan sebaya. Kedua, arena informal yang membuat para aktor lebih cair dalam berdialog. Ketiga, kesetaraan yang memungkinkan terjadinya pertukaran pengetahuan atas realitas dunia antar anggota kelompok. Keempat, sifat khas kaum muda yang memiliki kecenderungan lebih mempercayai teman daripada orang lain.

Dalam lingkungan pertemanan sebaya ini terjadi proses pendidikan yang seringkali terabaikan dalam kehidupan sehari-hari, yaitu pendidikan yang menjangkau ranah kehidupan nyata, pandangan tentang dunia, dan pengalaman-pengalaman hidup yang dialami oleh para aktor. Pertemanan sebaya dapat memiliki makna dan guna untuk menghindarkan kaum muda agar tidak terjerumus pada gerakan radikal keagamaan. Selain itu, secara hikmah, pertukaran kode dalam lingkungan pertemanan sebaya dapat menjadi suatu aktivitas dakwah yang ma'rūf dan tanggung jawab sosial personal untuk menyelamatkan orang-orang di sekitarnya untuk mendukung Islam yang ramah, lembut, dan membumi, sebagai pengejawantahan rahmatan li 'l- 'ālaminn.[w] 


\section{BIBLIOGRAFI}

Abercrombie, Nicholas dan Alan Warde, Contemporary British Society Third Edition, Cambridge: Cambridge University Press, 2000.

Abuza, Zachary, Political Islam and Violence in Indonesia, New York: Routledge, 2007.

Azra, Azyumardi, Pergolakan Politik Islam: Dari Fundamentalisme, Modernisme hingga Post-Modernisme, Jakarta: Paramadina, 2006.

Brake, Mike, The Sociology of Youth Culture and Youth Subculture: Sex Drugs and Rock ' $n$ ' Roll, New York: Routledge, 2013.

Brown, Bradford B. dan Christa Klute, "Cliques, Crowds, and Friendships", dalam Gerald R. Adams and Michael D. Berzonsky (ed.), Blackwell Handbook of Adolescence, Malden: Blackwell, 2003.

Cattrijse, Lieve, Human Rights Education: One Step Beyond in Search of a Conceptual Framework for Human Rights Education, Ghent: Ghent University, 2009.

Coulon, Alain, Etnometodologi, cet. III, Jakarta: Lengge, 2008.

Cuff, E.C, W.W. Sharrock dan D.W. Francis, Perpectives in Sociology, Ed. V, New York: Routledge, 2006.

Hoppers, Wim, Integrating Formal and non-Formal Basic Education: Policy and Practice in Uganda, Paris: IIEP, 2008.

H.S., Hairus Salim, Najib Kaelani, dan Nikmal Azekiyah, Politik Ruang Publik Sekolah Negosiasi di Sekolah Menengah Umum Negeri di Yogyakarta, Yogyakarta: UGM, 2011.

Lagdridge, Darren, Phenomenological Pschycology: Theory, Research and Methods, London: Pearson, 2007.

Ritzer, George, Teori Sosiologi Dari Sosiologi Klasik Hingga Perkembangan Terakhir Postmodern, ed. VIII, terj., Yogyakarta: Pustaka Pelajar, 2012.

Scheff, Thomas J, Goffman Unbound! a New Paradigm for Social Science, London: Paradigm Publisher, 2006.

Sean Byrne dan Amos Nadan, "The Social Cube Analytical Model and Protracted Ethoterritorial Conflicts", dalam Thomas Matyok, et.al (eds.), Critical Issues In Peace and Conflict Studies, Plymouth: Lexington Books, 2011.

Walisongo, Volume 23, Nomor 1, Mei 2015 


\section{Internet:}

Azca, Muhammad Najib, "Yang Muda yang Radikal: Refleksi Sosiologis terhadap Fenomena Radikalisme Kaum Muda Muslimdi Indonesia Pasca Orde Baru", Maarif, Vol. 8, No. 1, Juni 2011, http://maarifinstitute.org/images/ ../vol\%20viii\%20no\%201\%20juli\%20201.pdf, diakses pada tanggal 2 Maret 2015.

Bruinessen, Martin V, "Genealogies of Islamic Radicalism in Post Suharto Indonesia”, South East Asia Research, Vol. 10, No. 2, tahun 2002, http:// www.dspace. library.uu.nl/bitstream/handle/1874/20378/bruinessen_02_genealogies_isla micradicalism.pdf?sequence=1, diakses pada tanggal 3 Maret 2015.

Dwiningrum, Siti Irene Astuti, "Multicultural Da'wa in Schools From Sociological Persepectives", Jurnal Walisongo, Vol. 22, No. 2, November 2014, http:// portalgaruda.org/?ref=browse\&mod=viewissue\&journal=5939\&issue=\%20 Vol\%2022,/\%2/0No\%202\%20(2014):\%20Dakwah\%20Multikultural, diakses pada tanggal 9 Maret 2015.

Kleden, Ignas, "Pierre Bourdieu dan Konsep Habitus Baru", diterbitkan melalui http://www.habitusbaru.com, diakses pada tanggal 4 Maret 2015.

Munip, Abdul, "Menangkal Radikalisme Agama di Sekolah", Jurnal Pendidikan Islam, Vol. 1 No 2. Desember 2012 dalam, http://journal.uin-suka.ac.id/jurnal/artikel/ 133/menangkal-radikalisme-agama-disekolah, diakses pada tanggal 2 Februari 2015.

Rijal, Syamsul, "Radikalisme Islam Klasik dan Kontemporer: Membanding Khawarij dan Hizbut Tahrir", Jurnal al-Fikr, Vol. 14, No. 2, tahun 2010, http://www.uinalauddin.ac.id/download-5.Syamsul\%20Rijal.pdf, diakses pada tanggal 2 Februari 2015.

Robert, Robertus dan U. Abdul Rojak, "Proses Sosial Sebagai Medium Pembelajaran: Konseptualisasi Habitus Untuk Sosiologi-Pedagogis", Jurnal Sosialita, Vol 9, No. 1. Juni 2011, dalam http://unj.ac.id/fis/sites/default/ files/eman_sosialita_ 912011_0.pdf, diakses pada tanggal 4 Maret 2015.

Rokhmad, Abu, "Radikalisme Islam dan Upaya Deradikalisasi Paham Radikal", Walisongo, Vol 20, No.1, Mei 2012, http://eprints.walisongo.ac.id/1931/ 1/Abu_Rokhmad-Radikalisme_Islam. pdf, diakses tanggal 4 Maret 2015.

Tittley, Mark, "Youth Subcultures and Commitment Level Model”, http://www. btc.co.za, diakses pada tanggal 10 Maret 2015.

United Nations, Division for Social Policy and Development, "Definition of Youth", http://www.un.org/esa, diakses pada tanggal 10 Maret 2015. 